\title{
Lack of Seasonal Variations in Vitamin D Concentrations among Hospitalized Elderly Patients
}

\author{
Justyna Nowak ${ }^{1, *}$, Bartosz Hudzik ${ }^{1,2}$, Paweł Jagielski ${ }^{3}{ }^{\circledR}$, Karolina Kulik-Kupka ${ }^{4}$, Aleksander Danikiewicz ${ }^{4}$ \\ and Barbara Zubelewicz-Szkodzińska ${ }^{4}$ (D)
}

1 Department of Cardiovascular Disease Prevention, Department of Metabolic Disease Prevention, Faculty of Health Sciences in Bytom, Medical University of Silesia, 41-900 Bytom, Poland; bhudzik@sum.edu.pl

2 Third Department of Cardiology, Silesian Center for Heart Disease, Faculty of Medical Sciences in Zabrze, Medical University of Silesia, 41-800 Zabrze, Poland

3 Department of Nutrition and Drug Research, Faculty of Health Science, Jagiellonian University Medical College, 31-007 Cracow, Poland; paweljan.jagielski@uj.edu.pl

4 Department of Nutrition-Related Disease Prevention, Department of Metabolic Disease Prevention, Faculty of Health Sciences in Bytom, Medical University of Silesia, 41-900 Bytom, Poland; karolina_kulik@interia.pl (K.K.-K.); adanikiewicz@sum.edu.pl (A.D.); bzubelewicz-szkodzinska@sum.edu.pl (B.Z.-S.)

* Correspondence: justyna.nowak@sum.edu.pl; Tel.: +483-2397-6541

check for updates

Citation: Nowak, J.; Hudzik, B.; Jagielski, P.; Kulik-Kupka, K.; Danikiewicz, A.; ZubelewiczSzkodzińska, B. Lack of Seasonal Variations in Vitamin D Concentrations among Hospitalized Elderly Patients. Int. J. Environ. Res. Public Health 2021, 18, 1676. https://doi.org/10.3390/ ijerph18041676

Received: 8 December 2020

Accepted: 7 February 2021

Published: 9 February 2021

Publisher's Note: MDPI stays neutral with regard to jurisdictional claims in published maps and institutional affiliations.

Copyright: (c) 2021 by the authors. Licensee MDPI, Basel, Switzerland. This article is an open access article distributed under the terms and conditions of the Creative Commons Attribution (CC BY) license (https:// creativecommons.org/licenses/by/ $4.0 /)$.
Abstract: Background. Generally, most vitamin D in the human body (90-95\%) is produced in the skin during exposure to sunlight. The effectiveness of this process depends on several biological and physical factors, e.g., age or latitude. Skin synthesis of vitamin D among elderly people is reduced. The aim of the study was to assess serum 25-hydroxyvitamin D [25(OH)D] seasonal variations in elderly patients hospitalized at the geriatric department. Methods. The study was carried out on 242 patients aged 60 years or older hospitalized at the geriatric department. The study group was categorized by four seasons as well as month. Results. The median (interquartile range) $25(\mathrm{OH}) \mathrm{D}$ concentration among all patients $(n=242)$ was $33.95(26.96-45.18) \mathrm{nmol} / \mathrm{L}$. There was no statistical significance in the median serum $25(\mathrm{OH}) \mathrm{D}$ concentration with regard to each of the four seasons: in the spring $32.95(25.96-43.68) \mathrm{nmol} / \mathrm{L}$, in the summer $38.69(27.46-50.67) \mathrm{nmol} / \mathrm{L}$, in the autumn 33.45 (27.08-44.18) nmol/L, in the winter $34.57(23.46-43.93) \mathrm{nmol} / \mathrm{L},(p=0.48)$. Conclusions. Vitamin $\mathrm{D}$ deficiency was observed in all geriatric patients, irrespective of the season. The results of the study indicate no significant differences in median vitamin D concentration among the hospitalized patients across all four seasons. Even in the summer months, in our climate, it is fairly difficult for an elderly person to produce an adequate amount of vitamin D through the skin. Therefore, proper vitamin D supplementation is recommended and should be implemented in the elderly irrespective of the season.

Keywords: vitamin D; season; elderly people; vitamin D deficiency

\section{Introduction}

Vitamin D is a fat-soluble vitamin but is more like secosteroid hormone [1]. The well-known function of this vitamin is bone and calcium/phosphorous homeostasis as well as musculoskeletal system modulation. The extraskeletal effects of vitamin D in the last few years are still a matter of debate [1]. The active form of vitamin D-1,25-dihydroxyvitamin $\mathrm{D}_{3}$ regulates multiple cellular processes (including cell proliferation, differentiation, apoptosis, angiogenesis and immune modulation) as the vitamin $\mathrm{D}$ receptors are present in the kidneys, heart and immune cells [2], cancer cells of the prostate, breast and colon [1,3]. Vitamin D deficiency is correlated with the common prevalence of metabolic and cardiovascular diseases (hypertension, type 1 diabetes mellitus, stroke or myocardial infarction), 
several autoimmune diseases (including multiple sclerosis, inflammatory bowel disease, rheumatoid arthritis, systemic lupus erythematosus) [2,3].

Vitamin $\mathrm{D}$ is an umbrella term for two forms. The first form-the vitamin $\mathrm{D}_{2}$ (ergocalciferol), is synthesized by ultraviolet B light (UVB) from the ergosterol in yeast and fungi. Vitamin $\mathrm{D}_{2}$ in the diet comes from plants and fungi. The second form-vitamin $\mathrm{D}_{3}$ (cholecalciferol) is synthesized from 7-dehydrocholesterol in the skin via UVB sunlight exposure and in the diet comes from animal products (e.g., fatty fish-eel, wild salmon, herring, mackerel, sardines, some fish oils-cod liver oil, eggs, dairy products) [1,4]. Most of the vitamin D in the human body comes from skin synthesis. Next, 7-dehydrocholesterol in the skin is converted to pre-vitamin $\mathrm{D}_{3}$ (a thermodynamically unstable pre-vitamin $\mathrm{D}_{3}$ form) and later to more stable form-vitamin $\mathrm{D}_{3}$ (cholecalciferol) [1,3,4]. Vitamin $\mathrm{D}$ (either formed in the skin and absorbed from the diet) is transported in the blood by vitamin $\mathrm{D}$ binding protein to the liver where it is hydroxylated by vitamin D 25-hydroxylase (CYP2R1) and form 25 -hydroxy vitamin $\mathrm{D}-25(\mathrm{OH}) \mathrm{D}_{3}$-calcidiol. This is the major circulating form of vitamin $\mathrm{D}$ and the accepted biomarker for vitamin $\mathrm{D}$ status $[1,3,4]$. Finally, $25(\mathrm{OH}) \mathrm{D}_{3}$ is transported to the kidneys and hydroxylated by 1- $\alpha$-hydroxylase (CYP27B1) to form 1,25-dihydroxyvitamin $\mathrm{D}-1,25(\mathrm{OH})_{2} \mathrm{D}$-calcitriol, which is the biologically active form of vitamin D [1,4]. Many extrarenal tissues, mainly osteoclasts, colon, brain and blood cells such as macrophages, also express this enzyme, and that is why vitamin D can act in a paracrine and autocrine manner in these tissues $[5,6]$.

The effectiveness of vitamin D skin synthesis depends on the biological and physical factors, e.g., skin pigmentation, age, and latitude [7,8]. Physical factors including sunscreens, clothing, glass shielding may markedly reduce or completely eliminate the production of vitamin D in the skin (the use of sunscreen with a sun protection factor of 15 or higher prevents about $99 \%$ of dermal vitamin D production) [8]. The skin synthesis of vitamin D during winter months at latitudes above $37^{\circ} \mathrm{N}$ and below $37^{\circ} \mathrm{S}$ solar angle is insufficient [8]. Thus, in Poland, skin synthesis does not occur from October to March. Moreover, in Central Europeans, adequate conditions to skin synthesis of vitamin D are described as exposing $18 \%$ of the body to the sunlight without sunscreens for about $15 \mathrm{~min}$ a day between $10 \mathrm{AM}$ and 3 PM [7].

The biological factors that reduce vitamin $\mathrm{D}$ production and bioavailability are skin pigmentation (increased skin pigmentation can reduce dermal produce vitamin $\mathrm{D}$ as much as $99.9 \%$ ), fat malabsorption, body fat content, medication use, and age [7-9]. A decreased cutaneous synthesis of vitamin D is reported in elderly people. Aging is associated with a significant decrease of 7-dehydrocholesterol skin synthesis caused by structural changes in the dermis-shrinkage and decreased elasticity of the papillary dermis and a decrease in superficial loops on the papillary body beneath the dermis. Thus, a 70-year-old person produces $75 \%$ less vitamin D via skin synthesis compared with a 20-year-old person [8,9]. Lower vitamin D concentrations in elderly people in comparison to younger people are reported throughout the whole year irrespective of the season [8].

Elderly people are at risk of developing vitamin D deficiency caused by various factors such as decreased dietary intake and impaired intestinal absorption, reduced sunlight exposure, impaired skin synthesis, and hydroxylation in the liver and kidneys $[4,8,10]$.

The evidence examining seasonal variations in vitamin D concentration among the elderly is scarce [11]. There are also, to our knowledge, no studies of this type searching for seasonal changes in the same cohort in regions at latitude $50^{\circ} 17^{\prime} 51^{\prime \prime} \mathrm{N}$, where sunlight is not adequate throughout the year. Therefore, we have set out to investigate seasonal variations of serum $25(\mathrm{OH}) \mathrm{D}$ in elderly patients hospitalized at the geriatrics department.

\section{Methods}

\subsection{Study Population}

The study was carried out with 422 patients over 60 years hospitalized at the geriatric department of a county hospital in Piekary Slaskie, Silesia, located in the south of Poland $\left(50^{\circ} \mathrm{N}\right)$. In this region, skin synthesis does not occur from October to March [7]. The data on 
clinical presentation, baseline characteristics and laboratory examinations were obtained from the electronic medical records. Exclusion criteria included marked physical and/or mental impairment, liver disorders, decompensated thyroid disease, cancer, anticonvulsants or glucocorticosteroid use, vitamin D supplements use within the 3 months prior to admission. Two hundred forty-two elderly individuals met inclusion criteria. The study was conducted in accordance with the Declaration of Helsinki was approved by the Bioethics Committee of the Medical University of Silesia, Katowice, Poland. All the participants provided written informed consent before participating in the study.

\subsection{Methods}

The study was performed in 2013. Venous blood samples were collected after overnight fasting at admission. Samples were centrifuged to separate serum. The laboratory workup was done on each sample on the day of collection. The blood samples were not stored. The study group was categorized by four seasons: spring $(n=61$, blood samples collected between 21 March to 20 June), summer ( $n=77$, blood samples collected between 21 June to 22 September), autumn ( $n=64$, blood samples collected between 23 September to 21 December), winter ( $n=40$, blood samples collected between 22 December to 20 March) and moths.

\subsection{Laboratory Measurements}

Serum $25(\mathrm{OH}) \mathrm{D}$ concentration $(\mathrm{nmol} / \mathrm{L})$ was measured using an enzyme-linked immunosorbent assay (ELISA) (Architect 25-OH vitamin D test, detection range: 10 $400 \mathrm{nmol} / \mathrm{L}, \% \mathrm{CV}: \leq 10)$. Ingested and cutaneously produced vitamin $\mathrm{D}$ is rapidly converted to $25(\mathrm{OH}) \mathrm{D}$, but in serum, only a fraction of $25(\mathrm{OH}) \mathrm{D}$ is converted to its active metabolite 1,25(OH)2D. Thus, measurement of the total 25(OH)D concentration is the best test to assess body stores of vitamin $\mathrm{D}$. The total 25(OH)D concentration allowed for the diagnosis and monitoring of vitamin D deficiency, whereas quantification of 25(OH)D2 and $25(\mathrm{OH}) \mathrm{D} 3$ fractions can facilitate treatment monitoring [12]. In the laboratory, each step of the diagnostic process was constantly monitored and controlled. Measurement was conducted according to a quality management system compatible with the standard EN-PN 9001:2008.

According to the diagnostic threshold defining serum 25(OH)D concentration approved for Central Europe, serum 25(OH)D concentrations $\leq 50.0 \mathrm{nmol} / \mathrm{L}$ were considered as vitamin D deficient, while concentrations between $>50.0 \mathrm{nmol} / \mathrm{L}$ and $75.0 \mathrm{nmol} / \mathrm{L}$ were classified as suboptimal vitamin $\mathrm{D}$ status. Concentrations between $>75.0 \mathrm{nmol} / \mathrm{L}-$ $125.0 \mathrm{nmol} / \mathrm{L}$ were defined as adequate vitamin D status [7].

\subsection{Statistical Analysis}

A Shapiro-Wilk test was used to evaluate the normality of variables. Normally distributed data were compared using the Student's t-test or analysis of variance (ANOVA), while nonparametric data were compared using the Mann-Whitney $U$ test and the KruskalWallis test, respectively. Analyzed variables are expressed as mean \pm SD (for normally distributed data) as well as median, quartile lower and quartile upper (for nonparametric data). A probability level of $p \leq 0.05$ was considered to be significant. The data were analyzed using the statistical software STATISTICA 13 PL (Tulsa, Oklahoma, OK, USA).

\section{Results}

\subsection{Characteristics of the Study Group}

A total of 242 patients (70 males, 172 females) with a median age of 78.0 (72.0-83.0) years were included in the study. The median age of women was 79.0 (73.0-83.0) years; the median age of men was $77.50(72.0-83.0)$ years $(p=0.567)$. Most of the participants in our study were lived in the town $(84.7 \%)$, while $15.3 \%$ were lived in the village. The main characteristics of the study group are shown in Table 1. 
Table 1. Baseline characteristics of the study group $(n=242)$.

\begin{tabular}{|c|c|c|c|c|c|c|}
\hline Parameter & Total $(n=242)$ & Spring $(n=61)$ & $\begin{array}{c}\text { Summer } \\
(n=77)\end{array}$ & $\begin{array}{l}\text { Autumn } \\
(n=64)\end{array}$ & Winter $(n=40)$ & $p$ \\
\hline Female $n(\%)$ & $172(71.1)$ & $39(63.9)$ & $57(74.0)$ & 49 (76.6) & $27(67.5)$ & 0.38 \\
\hline Age (years) & $78(72-83)$ & $80(73-85)$ & $78(72-83)$ & $78(72-81)$ & 77 (74-83.5) & 0.38 \\
\hline $\operatorname{BMI}\left(\mathrm{kg} / \mathrm{m}^{2}\right)$ & $14(24-31)$ & $26(23-30)$ & $27(24-30)$ & $28(25-32)$ & $28(25-34)$ & 0.09 \\
\hline $\begin{array}{l}\text { Length of hospitalized } \\
\text { (days) }\end{array}$ & $10(8-12)$ & $10(8-14)$ & $10(8-11.5)$ & $10(8-12)$ & $10(9-12)$ & 0.36 \\
\hline $\begin{array}{c}\text { Arterial hypertension } n \\
(\%)\end{array}$ & $198(81.8)$ & $48(78.7)$ & $60(77.9)$ & $54(84.4)$ & $36(90.0)$ & 0.35 \\
\hline $\begin{array}{c}\text { Diabetes mellitus } \\
n(\%)\end{array}$ & $85(35.1)$ & $16(26.2)$ & $31(40.3)$ & $20(31.3)$ & $18(45.0)$ & 0.16 \\
\hline $\begin{array}{c}\text { Hypercholesterolemia } n \\
(\%)\end{array}$ & $70(28.9)$ & $14(23.0)$ & $27(35.1)$ & $18(28.1)$ & $11(27.5)$ & 0.46 \\
\hline Hyperlipidemia $n(\%)$ & $18(7.4)$ & $5(8.2)$ & $2(2.6)$ & $8(12.5)$ & $3(7.5)$ & 0.16 \\
\hline CAD $n(\%)$ & $87(36.0)$ & $18(29.5)$ & $27(35.1)$ & $26(40.6)$ & $16(40.0)$ & 0.56 \\
\hline HF $n(\%)$ & $63(26.0)$ & $19(31.1)$ & $20(26.0)$ & $14(21.9)$ & $19(47.5)$ & 0.03 \\
\hline Anemia $n(\%)$ & $65(26.9)$ & $18(29.5)$ & $19(24.7)$ & $17(26.6)$ & $11(27.5)$ & 0.93 \\
\hline CKD $n(\%)$ & $41(16.9)$ & $8(13.1)$ & $19(24.7)$ & 7 (10.9) & 7 (17.5) & 0.13 \\
\hline COPD $n(\%)$ & $21(8.7)$ & $5(8.2)$ & $7(9.1)$ & $7(10.9)$ & $2(5,0)$ & 0.76 \\
\hline Stroke $n(\%)$ & $23(9.5)$ & 7 (11.5) & $8(10.4)$ & $6(9.4)$ & $2(5.0)$ & 0.73 \\
\hline Obesity $n(\%)$ & $92(38.0)$ & $16(26.2)$ & $22(28.6)$ & $25(39.1)$ & $16(40.0)$ & 0.15 \\
\hline Overweight $n(\%)$ & $79(32.6)$ & $21(34.4)$ & $33(42.9)$ & $24(37.5)$ & $14(35.0)$ & 0.15 \\
\hline
\end{tabular}

Abbreviations: BMI—body mass index; CAD—coronary artery disease; HF—heart failure; CKD—chronic kidney disease; COPD— chronic obstructive pulmonary disease; arterial hypertension according to European Society of Hypertension/European Society of Cardiology (ESH/ESC) 2007 was recognized as SBP (systolic blood pressure): 140-159 (mmHg) and DBP (diastolic blood pressure): 90-99 $(\mathrm{mmHg})[13]$.

\subsection{Seasonal Variation of Serum 25(OH)D Concentrations}

Seasonal variation of serum $25(\mathrm{OH}) \mathrm{D}$ concentrations are shown in Table 2. The median serum 25(OH)D concentration among total patients $(n=242)$ was $33.95(26.96-$ $45.18) \mathrm{nmol} / \mathrm{L}$. There were no statistically significant differences in the median serum of $25(\mathrm{OH}) \mathrm{D}$ concentration during seasons $(p=0.480)$.

Table 2. Serum 25(OH)D concentrations ( $\mathrm{nmol} / \mathrm{L})$ across all seasons $(n=242)$.

\begin{tabular}{ccc}
\hline & Median (Q1-Q3) & $p$ \\
\hline Spring & $32.95(25.96-43.68)$ & \\
\hline Summer & $38.69(27.46-50.67)$ & 0.480 \\
\hline Autumn & $33.45(27.08-44.18)$ & \\
\hline Winter & $34.57(23.46-43.93)$ & \\
\hline Total & $33.95(29.96-45.18)$ \\
\hline
\end{tabular}

Q1, lower of quartile; Q3, upper of quartile.

Most of the participants ( $n=193 ; 79.8 \%$ ) had vitamin D deficiency. Suboptimal vitamin D concentration was observed in $46(19.0 \%)$ patients. Only three patients had adequate vitamin $\mathrm{D}$ concentration (these patients were connected to the group patients with suboptimal vitamin D). The proportion of patients with $25(\mathrm{OH}) \mathrm{D}$ deficiency was similar between seasons-respectively $83.6 \%$ in spring, $72.7 \%$ in summer, $81.2 \%$ in autumn 
and $85.0 \%$ in winter. The proportion of suboptimal vitamin D concentration was the same, similar across each season, $p=0.297$ (Table 3).

Table 3. Status of serum 25(OH)D concentrations during seasons $(n=242)$.

\begin{tabular}{|c|c|c|c|c|c|}
\hline & $n$ & $\begin{array}{c}\text { Deficiency } \\
25(\mathrm{OH}) \mathrm{D} \\
\leq 50.0 \mathrm{nmol} / \mathrm{L}\end{array}$ & $\begin{array}{c}\text { Suboptimal } \\
25(\mathrm{OH}) \mathrm{D} \\
>50.0-75.0 \mathrm{nmol} / \mathrm{L}\end{array}$ & $\begin{array}{c}\text { Adequate } \\
\text { 25(OH)D } \\
>75.0-125.0 \mathrm{nmol} / \mathrm{L}\end{array}$ & $p$ \\
\hline & & $n(\%)$ & $n(\%)$ & $n(\%)$ & \multirow{5}{*}{0.297} \\
\hline Spring & 61 & 51 (83.6) & $9(14.8)$ & 1 (1.6) & \\
\hline Summer & 77 & $56(72.7)$ & $20(26.0)$ & $1(1.3)$ & \\
\hline Autumn & 64 & $52(81.2)$ & $12(18.8)$ & $0(0.0)$ & \\
\hline Winter & 40 & $34(85.0)$ & $5(12.5)$ & $1(2.5)$ & \\
\hline Total & 242 & $193(79.8)$ & $46(19.0)$ & $3(1.2)$ & \\
\hline
\end{tabular}

Table 4 shows the median serum 25(OH)D concentrations for each month. There were no statistically significant differences in the median serum $25(\mathrm{OH}) \mathrm{D}$ concentration among respective months $(p=0.193)$.

Table 4. Median serum 25(OH)D concentrations (nmol/L) of patients hospitalized in each month $(n=242)$.

\begin{tabular}{|c|c|c|c|}
\hline & $n(\%)$ & $\begin{array}{l}\text { Median } \\
\text { (Q1-Q3) }\end{array}$ & $p$ \\
\hline January & $14(5.8)$ & $43.56(23.71-50.67)$ & \multirow{12}{*}{0.193} \\
\hline February & $14(5.8)$ & $36.69(25.71-43.68)$ & \\
\hline March & $17(7.0)$ & $30.45(21.22-34.44)$ & \\
\hline April & $18(7.4)$ & $31.95(27.21-46.68)$ & \\
\hline May & $21(8.7)$ & $32.70(23.21-38.69)$ & \\
\hline June & $20(8.3)$ & $35.69(27.46-49.42)$ & \\
\hline July & $28(11.5)$ & $42.18(31.08-53.41)$ & \\
\hline August & $24(9.9)$ & $37.44(27.46-50.54)$ & \\
\hline September & $30(12.4)$ & $33.45(22.46-47.92)$ & \\
\hline October & $14(5.8)$ & $36.57(28.45-49.92)$ & \\
\hline November & $22(9.1)$ & $30.58(25.96-35.44)$ & \\
\hline December & $20(8.3)$ & $34.44(28.70-46.80)$ & \\
\hline
\end{tabular}

Abbreviations: SD—standard deviation; Q1-lower of quartile; Q3-upper of quartile.

\section{Discussion}

In physiological conditions, most vitamin D (90-95\%) is produced in the skin tissue during sun exposure. Vitamin D concentration is related to many factors such as various unchangeable factors, such as season, time of day, latitude, air pollution, weather conditions, etc., as well as others like time spent outdoor, using sun protection cream, diet, body mass, etc. Vitamin D concentration also depends on age, race, pigmentation, etc. [8]. Season-dependent vitamin D deficiency has been described, especially during the winter [14]. Poland, as a country located in Central Europe on latitude between 49 and $54^{\circ} \mathrm{N}$, has vitamin D skin synthesis present mainly between late April and early September. From October to March, skin synthesis of vitamin D does not occur [7].

Diet is the second source of vitamin D. In Poland; it is a significantly less effective source (compared to skin synthesis). Dietary sources of vitamin D include mainly comprise fatty fish (e.g., eel, wild salmon, herring, mackerel, sardines), some fish oils (e.g., cod liver 
oil) and to a lesser amount-egg yolk, cheese, milk and some mushrooms. This kind of foods (especially oily fish) are consumed in low amount in particular among elderly people. In some countries, a mandatory fortification of selected food products (milk or dairy products, orange juice, margarine, cereals) is provided. This depends on the health policy and governmental strategies of countries. In the United States, some foods are fortified in vitamin D (e.g., milk, some cereals, orange juice, yogurts, margarine). In European countries, mostly margarine and some cereals are fortified. In Poland, food fortification has not been customary. Some suggest shown that is the reason for the pandemic of vitamin $\mathrm{D}$ deficiency in Poland. Evaluation of the composition of diet in different populations showed that when an additional source of vitamin D is reduced (skin synthesis), even a varied and balanced diet cannot serve to match the complete vitamin $D$ requirement $[8,15]$. In our study, we did not assess the dietary intake of vitamin D. We only excluded patients with supplementation of vitamin D three months before being admitted to the hospital.

We have demonstrated that vitamin D deficiency is common among elderly patients $(79.80 \%$ of patients had vitamin D concentration below or equal to $50.00 \mathrm{nmol} / \mathrm{L}$ ). There were only three patients who had an adequate vitamin D concentration. Admittedly, we have shown that the proportion of patients with $25(\mathrm{OH}) \mathrm{D}$ deficiency was similar in the spring as well as in the summer, in the autumn and in the winter (respectively $83.60 \%$, $72.70 \% 81.20 \%, 85.00 \%), p=0.297$. We observed the minimum median serum $25(\mathrm{OH})$ $\mathrm{D}$ concentration in March and the maximum in January. We did not find statistically significant differences in the medians of serum $25(\mathrm{OH}) \mathrm{D}$ concentration during seasons $(p=0.480)$ as well as between the respective months $(p=0.193)$.

Risk factors contributing to vitamin D deficiency among the elderly population include, e.g., increasing adiposity [4]. A systematic review and meta-analysis research indicates that the prevalence of vitamin D is more elevated in obese individuals. Vitamin $\mathrm{D}$ deficiency is associated with obesity, irrespective of age and latitude. One of the reasons for the relationship between obesity and vitamin D deficiency may be excess body fat that retains the vitamin D metabolites. The cholecalciferol produced by the skin or intake with the diet is partially sequestered by the body fat before being transported to the liver for hydroxylation [16]. In our study, over $70 \%$ of patients had excess body weight. There were no statistically significant differences $(p=0.348)$ in the median serum $25(\mathrm{OH}) \mathrm{D}$ concentration among group patients with normal weight $(31.70 \mathrm{nmol} / \mathrm{L})$, overweight $(35.44 \mathrm{nmol} / \mathrm{L})$ and obesity $(34.44 \mathrm{nmol} / \mathrm{L})$.

In the current study, we have set out to examine seasonal variations in $25(\mathrm{OH}) \mathrm{D}$ concentrations among elderly hospitalized patients, which is a somewhat specific population given the time amount spent indoors (i.e., hospitalization), although we have attempted to mitigate that effect by taking blood samples at admission. Studies show that people mostly staying in an indoor environment (e.g., shift workers and indoor workers) are consistently reported to be at a greater risk for vitamin D deficiency $[17,18]$. Several studies have described that exposure to sunlight itself in various populations is indeed enough for the serum vitamin D concentrations to increase during the summer. For example, Bozkurt et al. within a healthy population aged between 20 and 87 from Ankara region, Turkey, has shown a higher serum $25(\mathrm{OH}) \mathrm{D}$ concentration in the summer-54.62 $\pm 38.34 \mathrm{nmol} / \mathrm{L}$ $(n=173)$ in comparison to the winter-38.34 $\pm 23.72 \mathrm{nmol} / \mathrm{L}(n=262), p<0.001$. However, $25(\mathrm{OH}) \mathrm{D}$ insufficiency was still found in $94 \%$ of patients in the winter and $85 \%$ in the summer [19]. This high prevalence of vitamin D insufficiency occurs in this region despite the location of the study group (Turkey as a Mediterranean country; $39-56^{\circ} \mathrm{N}$ ). This seasonal difference in serum $25(\mathrm{OH})$ D concentration in this study population probably results from younger age and health status.

Similar results were observed among the elderly people of Mexican origin (Mexico, $\left.25^{\circ} \mathrm{N}\right)$, where the serum $25(\mathrm{OH}) \mathrm{D}$ concentration was lower in the winter compared to the summer $(p<0.05)$ and autumn $(p<0.001)$. The lowest serum 25(OH)D concentration- 46.92 $\pm 18.72 \mathrm{nmol} / \mathrm{L}$ were observed among the study population in the winter and has risen in the spring to $49.92 \pm 18.22 \mathrm{nmol} / \mathrm{L}$ when reached its maximum of $52.41 \pm 18.22 \mathrm{nmol} / \mathrm{L}$ (in 
summer) and $54.66 \pm 19.72 \mathrm{nmol} / \mathrm{L}$ (in autumn). Moreover, in this study, the prevalence of vitamin D deficiency and insufficiency were around $90 \%$ [11].

Another study by Lewandowski et al. with the same (as our study) geographical location but differs with respect to age and health status considers the mean serum $25(\mathrm{OH}) \mathrm{D}$ concentration in healthy Polish (aged 22-63). Summer serum 25(OH)D concentration were higher in comparison to winter serum $25(\mathrm{OH}) \mathrm{D}$ concentration $(51.87 \pm 18.05 \mathrm{vs.} 38.99 \pm$ $18.09 \mathrm{nmol} / \mathrm{L} ; p<0.001$ ) [20].

Another study conducted on 153 elderly individuals living in nursing homes in Brazil by Sousa et al. has shown some interesting results [21]. The mean serum 25(OH)D concentration was higher $(59.65 \pm 41.43 \mathrm{nmol} / \mathrm{L})$ than in our group, but still, most of this study group $(71.2 \%)$ had vitamin $\mathrm{D}$ concentration below the normal range $(25(\mathrm{OH}) \mathrm{D} \leq$ $72.38 \mathrm{nmol} / \mathrm{L}$ ). The study population consisted of elderly patients institutionalized in the region with high UV light exposure.

Cited studies $[11,19,21]$ have shown that even in the countries with high and very high annual average UV indexes like Turkey, Mexico, Brazil, the prevalence of hypovitaminosis $\mathrm{D}$ among elderly people is common even during the summer. It could be caused by the fact that elderly people, in particular, try to avoid high temperatures and any sunlight exposure [22]. Another explanation is the fact that elderly people use sunscreen, cover themselves or have health conditions (so they spend more time indoor)), which in turn predispose them to a decreased skin synthesis of vitamin D [22].

Similar results were reported based on the analysis of Geriatric Rehabilitation Facility patients aged $<60$ years in Germany. In this study, $96 \%$ of patients were vitamin D values below $75.0 \mathrm{nmol} / \mathrm{L}$, similar to our study. Among both groups of patients, the concentration(s) of vitamin D was unaffected by the time of the year. Over summer months, mean serum $25(\mathrm{OH}) \mathrm{D}$ concentration was $26.70 \pm 22.34 \mathrm{nmol} / \mathrm{L}$, while over winter months were $23.19 \pm 20.12 \mathrm{nmol} / \mathrm{L}$. Despite high UV exposure over the summer, which should affect the vitamin D skin synthesis (in Poland as well as in Germany), 96\% of German patients had vitamin D deficiency [23].

Different results were demonstrated in another study carried out on a regular communitydwelling group of people aged $\geq 65$ also in Germany. It was reported that the serum $25(\mathrm{OH}) \mathrm{D}$ concentration was strongly associated with the seasons. The serum $25(\mathrm{OH}) \mathrm{D}$ concentration reached a minimum value of $38.44 \pm 16.37 \mathrm{nmol} / \mathrm{L}$ in March as the same as in our study-30.45 (21.22-34.44) nmol/L. Moreover, serum 25(OH)D concentration reached a maximum value in August- $63.89 \pm 16.45 \mathrm{nmol} / \mathrm{L}$, whereas, in our study, it was in January-43.56 (23.74-50.67) nmol/L. Unfortunately, in this study, the authors did not analyze the difference in vitamin D values across all four seasons [24].

Some interesting studies tried to investigate if time spent outdoors may change the serum concentration of vitamin D among the elderly. One of them was carried out on a group of patients aged $\leq 65$ in a psychiatric hospital in Norway. Individuals who spent less than 30 min outdoors every day (over the three months period before the study) had the mean serum $25(\mathrm{OH}) \mathrm{D}$ concentration at the concentration of $39.49 \pm 17.19 \mathrm{nmol} / \mathrm{L}$ and those who spent more than $60 \mathrm{~min}$ outdoors every day over the same period of time had the mean serum at the concentration of $33.99 \pm 14.00 \mathrm{nmol} / \mathrm{L}$. There was no significant difference. Similar to our study, the mean serum concentration of vitamin D was higher in summer, but the differences in concentration of vitamin $\mathrm{D}$ between seasons were not statistically significant [25]. Skin production of vitamin D is not efficient for over six months of the year due to the high latitude of the location of the hospital (Tromso in Norway) where the study was conducted.

The prevalence of vitamin D deficiency among patients (aged 19 or older) was described by Ostrowska et al. [26]. Patients hospitalized during the summer had a higher serum concentration of vitamin $\mathrm{D}$ in comparison to patients hospitalized during the winter ( $45.42 \pm 28.00$ vs. $36.39 \pm 27.48 \mathrm{nmol} / \mathrm{L}$, respectively; $p=0.001)$, but still, $93 \%$ of the patients hospitalized during the winter and as much as $86 \%$ of the patients hospitalized during the summer had serum 25(OH)D concentration below $75.0 \mathrm{nmol} / \mathrm{L}$. The high- 
est mean concentration of vitamin D was observed in June and the lowest in December $(p=0.034)$ [26]. The key factor of the differences between our study and the one mentioned above is younger age.

The seasonal variation of vitamin D among elderly people could not always be observed. Despite the higher concentration of vitamin D during the summer and lower during the winter or the early spring, vitamin D deficiency is still present $[11,19,21,23]$. It could be explained by an insufficient skin production of vitamin D among elderly individuals during the summer, even if the sunlight exposure exists. First, elderly people usually spend less time outdoors, but even if they go outside, they tend to be more active in the morning or late evening, so the effect of their skin synthesis of vitamin D over this time is reduced due to the insufficient UV light exposure $[4,8,10]$. Second, it can be reduced even more by using sunscreen or cloths, especially in our temperate climate, and above all, the most important cause of the insufficient skin synthesis of vitamin $\mathrm{D}$ is the reduction of 7-dehydrocholesterol concentration in the skin in comparison to each concentration among the group of younger people [8,9]. As it had been described, a 70-year-old person produces $75 \%$ less vitamin D via skin synthesis in comparison to a 20 year-one $[8,9]$. Moreover, it is essential for specialists to remember this fact whenever they work with elderly individuals.

The guidelines for vitamin D supplementation in Poland issued in 2018 [15] are consistent with the guidelines of Central Europe [7], and they take into account seasonal patterns. It is recommended that elderly people supplement vitamin D throughout the whole year. The reason for this supplementation is that the vitamin D is not produced in a sufficient amount even over the summer months [15].

\section{Study Limitations}

This study should be interpreted in view of its limitations. First and foremost, vitamin D status was assessed only once for each of the studied patients as such seasonal variations refer to the studied population, not a specific patient. Second, we lack information on sunlight exposure or sunscreen product use in the period preceding hospitalization-factors, which could have limited the efficacy of UVB exposure. Finally, there is a lack of a control group consisting of a healthy elderly population.

\section{Conclusions}

In conclusion, vitamin D deficiency was observed in all geriatric patients, irrespective of the season. The results of the study indicate no significant differences in median vitamin D concentration among the hospitalized patients across all four seasons. Even in the summer months, in our climate, it is fairly difficult for an elderly person to produce an adequate amount of vitamin D by the skin. Therefore, proper vitamin D supplementation should be recommended and implemented in the elderly irrespective of the season.

Author Contributions: Conceptualization, J.N., B.Z.-S.; methodology, J.N., K.K.-K., A.D., B.H.; software, B.H. and P.J.; validation, J.N. and B.Z.-S.; formal analysis, J.N., B.Z.-S., B.H.; investigation, J.N., K.K.-K.; resources, J.N., B.Z.-S., B.H.; data curation, J.N., P.J., A.D.; writing-original draft preparation, J.N., B.Z.-S., B.H.; writing-review and editing, J.N., B.Z.-S., B.H.; visualization, J.N., B.Z.-S., B.H.; supervision, J.N., B.Z.-S., B.H.; project administration, J.N.; funding acquisition, J.N., B.Z.-S. All authors have read and agreed to the published version of the manuscript.

Funding: Grant by the Medical University of Silesia (KNW-1-079/K/9/Z).

Institutional Review Board Statement: The study was conducted according to the guidelines of the Declaration of Helsinki, and approved by the bioethics board at the Medical University of Silesia $\mathrm{KNW} / 0022 / \mathrm{KB} 1 / 53 / 14)$.

Informed Consent Statement: Informed consent was obtained from all subjects involved in the study.

Data Availability Statement: All date are availability by address email of justyna.nowak@sum.edu.pl.

Conflicts of Interest: All authors declare no conflict of interest with regard to this manuscript. 


\section{References}

1. Umar, M.U.; Sastry, K.S.; Chouchane, A.I. Role of Vitamin D Beyond the Skeletal Function: A Review of the Molecular and Clinical Studies. Int. J. Mol. Sci. 2018, 19, 1618. [CrossRef] [PubMed]

2. Lai, Y.H.; Fang, T.C. The Pleiotropic Effect of Vitamin D. ISRN Nephrol. 2013. [CrossRef] [PubMed]

3. Christakos, S.; Dhawan, P.; Verstuyf, A.; Verlinden, L.; Carmeliet, G. Vitamin D: Metabolism, molecular, mechanism of action, and pleiotropic effects. Physiol. Rev. 2016, 96, 365-408. [CrossRef]

4. Meehan, M.; Penckofer, S. The Role of Vitamin D in the Aging Adult. J. Aging Gerontol. 2014, 2, 60-71. [CrossRef]

5. Pandolfi, F.; Franza, L.; Mandolini, C.; Conti, P. Immune modulation by vitamin D: Special emphasis on its role on prevention and treatment of cancer. Clin. Ther. 2017, 39, 884-89334. [CrossRef]

6. Gruber-Bzura, B. Vitamin D and influenza - prevention or therapy? Int. J. Mol. Sci. 2018, 19, 2419. [CrossRef] [PubMed]

7. Płudowski, P.; Karczmarewicz, E.; Bayer, M.; Carter, G.; Chlebna-Sokół, D.; Czech-Kowalska, J.; Dębski, R.; Desci, T.; Dobrzańska, A.; Franek, E.; et al. Practical guidelines for the supplementation of vitamin D and the treatment of deficits in Central Europe recommended vitamin D intakes in the general population and groups at risk of vitamin D deficiency. Endokrynol. Polska 2013, 64, 319-327.

8. Holick, M.F. High Prevalence of Vitamin D Inadequacy and Implications for Health. Mayo. Clin. Proc. 2006, 81, 353-373. [CrossRef]

9. McGreevy, C.; Williams, D. New Insight About Vitamin D and Cardiovascular Disease. Ann. Intern. Med. 2011, 155, 820-826. [CrossRef] [PubMed]

10. Garg, M.K.; Kharb, S.; Brar, K.S.; Mittal, R. Vitamin D Deficiency in Elderly: Implications, Prevention and Treatment. J. Indian Acad. Geriatr. 2012, 8, 77-82.

11. Elizondo-Montemayor, L.; Castillo, E.C.; Rodriguez-Lopez, C.; Villarreal-Calderón, J.R.; Gómez-Carmona, M.; Tenorio-Martínez, S.; Nieblas, B.; García-Rivas, G. Seasonal Variation in Vitamin D in Association with Age, Inflammatory Cytokines, Anthropometric Parameters, and Lifestyle Factors in Older Adults. Mediators Inflamm. 2017. [CrossRef] [PubMed]

12. Kennel, K.A.; Drake, M.T.; Hurley, D.L. Vitamin D deficiency in adults: When to test and how to treat. Mayo Clin. Proc. 2010, 8 , 752-757. [CrossRef]

13. Lionakis, N.; Mendrinos, D.; Sanidas, E.; Favatas, G.; Georgopoulou, M. Hypertension in the elderly. World J. Cardiol. 2012, 5, 135-147. [CrossRef] [PubMed]

14. Aydin, C.G.; Dincel, Y.M.; Arikan, Y.; Tas, S.K.; Deniz, S. The effect of indoor and outdoor sports participation and seasonal changes an vitamin D in athletes. SAGE Open Med. 2019, 7, 1-6. [CrossRef]

15. Rusińska, A.; Płudowski, P.; Walczak, M.; Borszewska-Kornacka, M.K.; Bossowski, A.; Chlebna-Sokół, D.; Czech-Kowalska, J.; Dobrzańska, A.; Franek, E.; Helwich, E.; et al. Vitamin D Supplementation Guidelines for General Population and Groups at Risk of Vitamin D Deficiency in Poland - Recommendations of the Polish Society of Pediatric Endocrinology and Diabetes and the Expert Panel With Participation of National Specialist Consultants and Representatives of Scientific Societies-2018 Update. Front. Endocrinol. 2018, 9, 246. [CrossRef]

16. Pereira-Santos, M.; Costa, P.R.F.; Assis, A.M.O.; Santos, C.A.S.T.; Santos, D.B. Obesity and vitamin D deficiency: A systematic review and meta-analysis. Obes. Rev. 2015, 16, 341-349. [CrossRef]

17. Coppeta, L.; Papa, F.; Magrini, A. Are Shiftwork and Indoor Work Related to D3 Vitamin Deficiency? A Systematic Review of Current Evidences. J. Environ. Public. Health 2018, 2018, 8468742. [CrossRef] [PubMed]

18. Divakar, U.; Sathish, T.; Soljak, M.; Bajpai, R.; Dunleavy, G.; Visvalingam, N.; Nazeha, N.; Soh, C.K.; Christopoulos, G.; Car, J. Prevalence of Vitamin D Deficiency and Its Associated Work-Related Factors among Indoor Workers in a Multi-Ethnic Southeast Asian Country. Int. J. Environ. Res. Public Health 2019, 17. [CrossRef] [PubMed]

19. Bozkurt, S.; Alkan, B.M.; Yildiz, F.; Gümüş, S.; Sezer, N.; Ardıçoğlu, Ö.; Akkus, S. Age, Sex, and Seasonal Variation in the Serum Vitamin D3 Levels in a Local Turkish Population. Arch. Rheumatol. 2014, 29, 14-19. [CrossRef]

20. Lewandowski, T.; Kałan, M.; Donica, H. Blood serum Vitamin D status evaluated in healthy people. Curr. Issues Oharm. Med. Sci. 2016, 26, 317-320.

21. Sousa, S.E.S.; Sales, M.C.; Araujo, J.R.T.; Sena-Evangelista, K.C.M.; Lima, K.C.; Pedrosa, L.C.F. High Prevalence of Hypovitaminosis D in Institutionalized Elderly Individuals is Associated with Summer in Region with High Ultraviolet Radiation Levels. Nutrients 2019, 11, 1516. [CrossRef]

22. Boucher, B.J. The Problems of Vitamin D Insufficiency in Older People. Aging Dis. 2012, 3, 313-329. [PubMed]

23. Schilling, S. Epidemic Vitamin D Deficiency Among Patients in an Elderly Care Rehabilitation Facility. Dtsch. Arztebl. Int. 2012, 109, 33-38. [CrossRef] [PubMed]

24. Klenk, J.; Rapp, K.; Denkkinger, M.D.; Nagel, G.; Nikolaus, T.; Peter, R.; Koenig, W.; Böhm, B.O.; Rothenbacher, D. Seasonality of vitamin D status in older people in Southern Germany: Implications for assessment. Age Ageing 2013, 42, 404-408. [CrossRef]

25. Gronli, O.; Kvamme, J.M.; Jorde, R.; Wynn, R. Vitamin D deficiency is common in psychogeriatric patients, independent of diagnosis. BMC Psychiatry 2014, 14, 134. [CrossRef] [PubMed]

26. Ostrowska, M.M.; Szulc-Mysińska, E.; Bobilewicz, D.; Faryna, M. Vitamin D (25-OH) concentrations in hospitalized patients, outpatients and dialysis patients depending on seasonal variation. J. Lab. Diagn. 2015, 51, 20-212. 